\title{
Hamil usia muda dan stunting pada balita usia 12-59 bulan di Kabupaten Lombok Timur
}

\author{
Catur Esty Pamungkas ${ }^{1}$, Siti Mardiyah WD ${ }^{2}$, Baiq Nurbaety ${ }^{3}$ \\ ${ }^{1,2}$ Program Studi DIII Kebidanan, Fakultas IImu Kesehatan, Universitas Muhammadiyah \\ Mataram, Indonesia, ${ }^{3}$ Program studi DIII Farmasi, Fakultas Ilmu Kesehatan, Universitas \\ Muhammadiyah Mataram, Indonesia
}

\begin{abstract}
Stunting indicates a chronic nutritional problem that happens for a long time. The presence of stunting is related to various factors, one of which is young pregnancy. The prevalence of stunting in East Lombok Regency increased by 34.6\% in 2016 to 35.1\% in 2017. Pregnancy when young increases the presence of stunting in toddlers, this is associated with the need for nutrition during pregnancy and the baby in the womb. Young pregnancy affects the behavior of mothers in the process of caring for babies, postpartum maternal behavior and the health of infants and baby, also affecting the growth of children and it cause stunting. The purposes of this study were to determine the effect of a young pregnancy with the incidence of stunting in children aged 12-59 months. The research method used was observational research with cross-sectional design. The research sample was of 789 respondents in infants aged 12-59 months with consecutive sampling techniques. Statistical analysis used was bivariate analysis with Chi Square and multivariate using logistic regression tests with significance level of $5 \%$ and $95 \% \mathrm{Cl}$. The results of the study showed that a woman that pregnant at a young age (<21 years) were 136 respondents (17\%), pregnant at a young age had a significant relationship with the incidence of stunting by controlling the family income variable, and the number of family members with an OR value is 1.59 (95\% Cl: $1.086-2,328)$. Family income became the dominant variable in this study with an OR value is $2,246(1,472-3,427)$.
\end{abstract}

Keywords: Young pregnancy, stunting, children aged 12-59 months

Stunting mengindikasikan masalah gizi kronis yang berlangsung lama. Kejadian stunting berhubungan dengan berbagai macam faktor salah satunya kehamilan saat muda. Prevalensi stunting di Kabupaten Lombok Timur meningkat yaitu sebesar 34,6\% pada tahun 2016 menjadi 35,1\% pada tahun 2017. Kehamilan saat muda meningkatkan kejadian stunting pada balita, hal ini dikaitkan dengan kebutuhan nutrisi selama hamil dan bayi yang dikandungnya. Kehamilan saat muda berdampak pada prilaku ibu saat mengasuh bayi, perilaku ibu postpartum serta kesehatan bayi dan anak, sehingga mempengaruhi pertumbuhan anak dan berakibat stunting. Penelitian ini bertujuan mengetahui pengaruh kehamilan usia muda dengan kejadian stunting pada balita usia 1259 bulan. Metode penelitian ini menggunakan penelitian observasional dengan rancangan cross sectional. Sampel penelitian sebanyak 789 responden pada anak balita usia 12-59 bulan dengan teknik consecutive sampling. Analisis uji statistik menggunakan analisis bivariate dengan Chi Square dan multivariate menggunakan uji regresi logistik dengan tingkat kemaknaan 5\% dan Cl 95\%. Hasil penelitian didapatkan ibu hamil saat usia muda (<21 tahun) sebanyak 136 responden (17\%), hamil usia muda memiliki hubungan bermakna dengan kejadian stunting dengan mengontrol variabel 
pendapatan keluarga, dan jumlah anggota keluarga dengan nilai OR 1.59 (Cl 95\%: 1.086-2.328).

Pendapatan keluarga menjadi variabel dominan dalam penelitian ini dengan nilai OR 2.246 (1.472-

3.427).

Kata Kunci : Hamil usia muda, stunting, balita usia 12-59 bulan

\footnotetext{
${ }^{*}$ Korespondensi Penulis : Catur Esti Pamungkas (email catur.esty@gmail.com)
}

\section{PENDAHULUAN}

Stunting mencerminkan kekurangan gizi kronis. Stunting mencerminkan kekurangan gizi kronis. selama periode paling kritis dari pertumbuhan dan perkembangan pada awal kehidupan. Stunting mengindikasikan akibat dari keadaan yang berlangsung lama, misalnya: kemiskinan dan pola asuha atau pemberian makanan yang kurang baik dari sejak anak dilahirkan yang mengakibatkan anak menjadi stunting (Kemenkes RI, 2010).

Tingkat global, padatahun 2011 sekitar 165 juta anak stunting tersebar di dunia secara tidak merata, 14 negara adalah rumah bagi $80 \%$ dari anak stunting dunia termasuk Asia (UNICEF, 2013). Di Indonesia diperkirakan 7,5 juta anak berusia dibawah lima tahun mengalami stunting dan memposisikan Indonesia masuk kedalam lima besar negara dengan jumlah anak dibawah lima tahun yang mengalami stunting tertinggi (UNICEF, 2013).

Prevalensi balita stunting di Indonesia meningkat yaitu pada tahun 2007 sebesar $(36,8 \%)$, tahun 2010 sebesar (35,6\%), tahun 2013 sebesar (37,2\%) dan Provinsi Nusa Tenggara Barat (NTB) berada pada urutan tertinggi ketiga prevalensi stunting di Indonesia setelah NTT dan papua barat dengan proporsi stunting 45,3\%, ini menunjukkan masalah kesehatan serius menurut klasifikasi WHO bila prevalensi $\geq 40$ (Riskesdas, 2013).

Prevalensi stunting di NTB meningkat, didapatkan 3 kabupaten dengan tingkat stunting tertinggi yaitu Lombok utara yaitu 40,3\% dari 21.578 balita, Lombok timur 34,6 \% dari 119.052 balita dan Lombok barat yaitu 33 \% dari 64.854 balita. Dilihat dari besarnya jumlah balita, kabupaten Lombok Timur menjadi kabupaten dengan jumlah balita terbanyak di NTB (Dinkes Provinsi NTB, 2017). Sehingga sangat penting untuk melakukan penelitian di kabupaten Lombok Timur.

Persentase perempuan yang pernah hamil dan umur pertama kali hamil dibawah usia 21 tahun menurut data BPS tahun 2017 di NTB sebesar 53,48\%. Kabupaten dengan prevalensi tertinggi yaitu
Kabupaten Lombok Timur sebesar 62,85\%, Lombok Tengah 58,69\% dan Lombok Barat 55,12\%. Berdasarkan data tersebut penelitian ini diarahkan untuk mengetahui hubungan kehamilan usia muda dengan kejadian stuntingdi Wilayah Kabupaten Lombok Timur.

langsung, khususnya pada balita berdampak jangka pendek meningkatnya morbiditas. Bila masalah ini bersifat kronis, maka akan mempengaruhi fungsi kognitif yakni tingkat kecerdasan yang rendah dan berdampak pada kualitas sumber daya manusia. Pada kondisi berulang (dalam siklus kehidupan) makanan yang mengalami kurang gizi diawal kehidupan (periode 1000 HPK) memiliki risiko penyakit tidak menular pada usia dewasa (Black RE, 2008).

Pertumbuhan Stunting yang terjadi pada usia dini dapat berlanjut dan berisiko untuk tumbuh pendek pada usia remaja. Anak yang tumbuh pendek pada usia dini (0-2 tahun) dan tetap pendek padausia 4-6 tahun memiliki risiko 27 kali untuk tetap pendek sebelum memasuki usia pubertas; sebaliknya anak yang tumbuh normal pada usia dini dapat mengalami growth faltering pada usia 4-6 tahun memiliki risiko 14 kali tumbuh pendek pada usia pra-pubertas.10 Oleh karena itu, intervensi untuk mencegah pertumbuhan Stunting masih tetap dibutuhkan bahkan setelah melampaui 1000 HPK (Aryastami NK, 2015). Periode 1000 hari pertama kehidupan (1000 HPK) merupakan simpul kritis sebagai awal terjadinya pertumbuhan Stunting, yang sebaliknya berdampak jangka panjang hingga berulang dalam siklus kehidupan.

Kabupaten Lombok Timur memiliki peningkatan kejadian stunting sebesar $34,6 \%$ pada tahun 2016 menjadi 35,1\% padatahun 2017. Hal ini menunjukkan stunting di Kabupaten Lombok Timur belum teratasi. Stunting sangat sulit untuk diatasi, intervensi jangka pendek hanya mampu mengatasi masalah stunting pada sepertiga anak. Hal ini mengisyaratkan bahwa faktor maternal dan antenatal berkontribusi terhadap masalah stunting (Bhutta, 2013). Beberapa peneliti menunjukkan hubungan 
faktor social ekonomi terhadap kejadian stunting pada anak. Pada penelitan (Wamani, 2007). didapatkan faktor-faktor yang mempengaruhi stunting adalah kultur, usia, keluarga, gender dan status social ekonomi. Dari beberapa peneliti diketahui banyak faktor yang mempengaruhi kejadian stunting, namun perlu adanya penelitian kaitannya kehamilan muda dengan kejadian stunting pada anak karena faktor ibu juga penyumbang terjadinya stunting. ini diperkuat dengan angka kelahiran dari remaja yaitu 75 dari 1000 perempuan (SDG, 2017).

Menurut data SDG untuk profil Provinsi Nusa

Tenggara Barat tahun 2015 didapatkan 15\% perempuan menikah sebelum usia 18 tahun, dengan prevalensi jumlah perempuan yang pernah kawin berumur 10-19 tahun di NTB tertinggi pada 3 kabupaten yaitu Lombok timur sebayak $72,58 \%$, Lombok tengah 71,69 dan lombok utara $65.4 \%$. Berdasarkan data tersebut kabupaten Lombok Timur menjadi kabupaten tertinggi jumlah perempuan yang menikah usia muda 10-19 (BPS, n.d.), hal tersebut menyumbang angka kehamilan di usia muda yang merupakan kondisi sangat beresiko untuk hamil. Oleh karena itu peneliti merasa perlu untuk mengaitkan pengaruh stunting dengan kehamilan.

\section{METODE}

Penelitian ini menggunakan jenis penelitian observasional dengan rancangan cross sectional. Sampel penelitian yaituanak balita stuntingusia 12-59 bulan dan balita normal usia 12-59 bulan yang tinggal di 18 puskesmas Wilayah Kabupaten Lombok Timur. Teknik pengambilan sampel dengan consecutive sampling. Analisis uji statistik yang digunakan adalah Analisis uji statistik yang digunakan adalahbivariate dengan Chi Square dan multivariate menggunakan uji regresi logistik dengan tingkat kemaknaan 5\% dan confidence interval $95 \%$.

Data yang dikumpulkan meliputi usia balita, jenis kelamin responden, hamil usia muda dengan pembagian uasia < 21tahun dan $\geq 21$ tahun berdasarkan (BKKBN, 2017), pendidikan ibu, pendapatan keluarga menurut SK Gubernur Nusa Tenggara Barat (NTB) nomor 561-815 Tahun 2017 tentang Upah Minimum Kabupaten Lombok Timur ditetapkan yaitu sebesar Rp. 1.831.000,- dan rendah jika pendapatan < Rp. 1.831.000,-, berat badan lahir < 2500 dikatakan BBLR dan $\geq 2500$ dikatakan tidak BBLR, penyakit infeksi kronis, Riwayat ASI Eksklusif dikatakan jika ibu memberikan ASI selama 6 bulan tanpa makanan pendamping ASI pada anak yang diteliti, Panjang badan lahir dikatakan pendek jika panjang $<47 \mathrm{~cm}$ dan normal $\geq 47 \mathrm{~cm}$, dan jumlah anggota keluar dari responden yang diteliti.

\section{HASIL DAN PEMBAHASAN}

Penelitian ini dilakukan pada 798 responden sesuai dengan criteria inklusi pada kelompok stunting dan kelompok normal. Hasil penelitian berdasarkan distribusi frekuensi karakteristik responden penelitian disajikan dalam table berikut :

Tabel 1. Distribusi Frekuensi Karakteristik Responden

\begin{tabular}{|c|c|c|c|c|c|c|}
\hline \multirow{3}{*}{ Karakteristik } & \multicolumn{4}{|c|}{ Kelompok } & \multirow{3}{*}{$\mathrm{N}$ (Total) } & \multirow{3}{*}{$\%$} \\
\hline & \multicolumn{2}{|c|}{ Stunting } & \multicolumn{2}{|c|}{ Normal } & & \\
\hline & $\mathrm{F}$ & $\%$ & $f$ & $\%$ & & \\
\hline \multicolumn{7}{|l|}{ Usia Balita } \\
\hline $12-23$ & 99 & 24,8 & 98 & 24,6 & 197 & 24,7 \\
\hline $24-59$ & 300 & 75,2 & 301 & 75,4 & 601 & 75,3 \\
\hline \multicolumn{7}{|l|}{ Jenis Kelamin } \\
\hline Perempuan & 175 & 43,9 & 186 & 46,6 & 361 & 45,2 \\
\hline Laki-laki & 224 & 56,1 & 213 & 53,4 & 437 & 54,8 \\
\hline \multicolumn{7}{|c|}{ Hamil usia muda } \\
\hline$<21$ & 79 & 19,8 & 57 & 14,3 & 136 & 17 \\
\hline$\geq 21$ & 320 & 80,2 & 342 & 85,7 & 662 & 83 \\
\hline \multicolumn{7}{|c|}{ Pendidikan ibu } \\
\hline Rendah & 282 & 70,7 & 266 & 66,7 & 548 & 68,7 \\
\hline Tinggi & 117 & 29,3 & 133 & 33,3 & 250 & 31,3 \\
\hline \multicolumn{7}{|c|}{ Pendapatan keluarga } \\
\hline Rendah & 360 & 90,2 & 324 & 81,5 & 684 & 85,8 \\
\hline Tinggi & 39 & 9,8 & 74 & 18,5 & 113 & 14,2 \\
\hline \multicolumn{7}{|c|}{ Berat badan lahir } \\
\hline BBLR & 27 & 6,8 & 19 & 4,8 & 46 & 5,8 \\
\hline Tidak BBLR & 372 & 93,2 & 380 & 95,2 & 752 & 94,2 \\
\hline
\end{tabular}




\begin{tabular}{|c|c|c|c|c|c|c|}
\hline \multicolumn{7}{|c|}{ Penyakit Infeksi kronis } \\
\hline Pernah & 31 & 7,8 & 23 & 5,8 & 54 & 6,7 \\
\hline Tidak pernah & 368 & 92,2 & 376 & 94,2 & 744 & 93,2 \\
\hline \multicolumn{7}{|l|}{ Asi Eksklusif } \\
\hline Tidak & 36 & 9 & 39 & 9,8 & 75 & 9,4 \\
\hline Ya & 363 & 91 & 360 & 90,2 & 723 & 90,6 \\
\hline \multicolumn{7}{|c|}{ Panjang Badan Lahir } \\
\hline$<47$ & 52 & 13 & 72 & 18 & 124 & 15,5 \\
\hline$\geq 47$ & 347 & 87 & 327 & 82 & 674 & 84,5 \\
\hline \multicolumn{7}{|c|}{ Jumlah anggota keluarga } \\
\hline$>4$ & 106 & 26,6 & 79 & 19,8 & 185 & 23,2 \\
\hline$\leq 4$ & 293 & 73,4 & 320 & 80,2 & 613 & 76,8 \\
\hline
\end{tabular}

Berdasarkan tabel 1. diketahui bahwa usia balita mayoritas usia balita 24-59 bulan, terbanyak pada kelompok balita normal yaitu 301 responden $(37,7 \%)$ dan begitu juga jenis kelamin balita mayoritas pada laki-laki, terbanyak pada kelompok stunting yaitu 224 responden (28,1\%). Hamil usia muda mayoritas pada usia $\geq 21$ tahun pada kelompok normal sebanyak 342 responden $(42,9 \%)$.

Pada penelitian ini mayoritas ibu memiliki pendidikan rendah yaitu sebanyak 282 responden (35.3\%) pada kelompok stunting, begitu juga pendapatan keluarga mayoritas rendah terbanyak pada kelompok balita stunting sebanyak 360 responden (45,2\%). Berat badan lahir mayoritas tidak BBLR pada kelompok balita normal yaitu 380 responden $(95,2)$. Penyakit infeksi kronis mayoritas tidak pernah terinfeksi sebanyak 376 responden $(65,4 \%)$ pada kelompok normal. Pada penelitian ini didapatkan mayoritas responden memberikan ASI eksklusif pada balita, dengan jumlah terbanyak pada kelompok balita stunting yaitu 363 reponden (91\%). Panjang badan lahir mayoritas terbanyak pada panjang badan $\geq 47 \mathrm{~cm}$ yaitu 347 responden (87\%). Pada penelitian ini terbanyak jumlah anggota keluarga 1-4 yaitu 320 (80,2\%) pada kelompok balita normal.

Tabel 2. Tabulasi silang hamil usia muda dengan kejadian stunting

\begin{tabular}{|c|c|c|c|c|c|}
\hline \multirow{2}{*}{ Hamil usia muda } & Stunting & Normal & \multirow{2}{*}{$P$-value } & \multirow{2}{*}{ OR } & \multirow{2}{*}{ Cl 95\% } \\
\hline & $\mathrm{n}$ & $\mathrm{n}$ & & & \\
\hline$<21$ & 79 & 57 & 0.038 & 1.481 & $1.020-2.151$ \\
\hline$\geq 21$ & 320 & 342 & & & \\
\hline
\end{tabular}

Berdasarkan tabel 2 terdapat hubungan hamil usia muda dengan kejadian stunting dengan nilai $p=0,038$ dengan nilai OR 1.481 (Cl 95\%:1.02-2.15). Hal tersebut dapat diinterpretasikan bahwa hamil usia muda beresiko 1,4 kali untuk terjadi stunting pada balita.

Rata-rata usia ibu saat hamil sama pada kedua kelompok yaitu usia 26 tahun. Pada dasarnya usia ibu hamil tersebut termasuk usia aman untuk hamil, namun pada penelitian ini mayoritas responden berpendapatan rendah pada kelompok balita stunting dengan rata-rata pendapatan Rp. 950.000 perbulan,ini dapat mempengaruhi ketersediaan pangan dalam keluarga dan kecukupan gizi balita dalam keluarga tersebut.

Hamil usia remaja berdampak terhadap pertumbuhan dan gizi remaja, mereka sangat rentan terhadap kekurangan gizi, sehingga kehamilan dan menyusui dapat meningkatkan risiko ini. Ketika remaja masih tumbuh, kehamilan dapat menyebabkan persaingan untuk nutrisi antara ibu dan janin, yang dapat mengakibatkan hasil yang merugikan bagi keduanya. 
Tabel 3. Tabulasi silang variabel luar dengan kejadian stunting

\begin{tabular}{|c|c|c|c|c|c|}
\hline Karakteristik & Stunting & Normal & $P$-Value & OR & Cl 95\% \\
\hline \multicolumn{6}{|l|}{ Pendidikan ibu } \\
\hline Rendah & 282 & 266 & 0.222 & 1.205 & $0.893-1.626$ \\
\hline Tinggi & 117 & 133 & & & \\
\hline \multicolumn{6}{|c|}{ Pendapatan keluarga } \\
\hline Rendah & 360 & 324 & 0.000 & 2.105 & $1.391-3.195$ \\
\hline Tinggi & 39 & 74 & & & \\
\hline \multicolumn{6}{|c|}{ Berat badan lahir } \\
\hline BBLR & 27 & 19 & 0.224 & 1.452 & $0.793-2.656$ \\
\hline Tidak BBLR & 372 & 380 & & & \\
\hline \multicolumn{6}{|c|}{ Penyakit Infeksi kronis } \\
\hline Pernah & 31 & 23 & 0.260 & 1.377 & $0.788-2.407$ \\
\hline Tidak pernah & 368 & 376 & & & \\
\hline \multicolumn{6}{|l|}{ Asi Eksklusif } \\
\hline Tidak & 36 & 39 & 0.716 & 0.915 & $0.569-1.473$ \\
\hline Ya & 363 & 360 & & & \\
\hline \multicolumn{6}{|c|}{ Panjang Badan Lahir } \\
\hline$<47$ & 52 & 72 & 0.051 & 0.681 & $0.462-1.003$ \\
\hline$\geq 47$ & 347 & 327 & & & \\
\hline \multicolumn{6}{|c|}{ Jumlah anggota keluarga } \\
\hline$>4$ & 106 & 79 & 0.024 & 1.465 & $1.052-2.042$ \\
\hline $1-4$ & 293 & 320 & & & \\
\hline
\end{tabular}

Hasil analisis didapatkan tidak ada hubungan yang bermakna secara statistik antara pendidikan ibu dengan kejadian stunting, namun ada kecendrungan pendidikan ibu yang rendah berpeluang 1,2 kali untuk terjadi stunting pada balita. Berdasarkan penelitian, yang dilakukan di Indonesian dalam survei kesehatan keluarga didapatkan hasil balita Stunting berhubungan dengan ibu yang tidak pernah mengikuti pendidikan formal dan kasus balita Stunting juga lebih tinggi di daerah pedesaan.

Berdasarkan tabel 3 didapatkan hubungan bermakna antara pendapatan keluarga rendah dengan kejadian stunting pada balita dilihat dari nilai $p=0,000$ dan nilai OR 2.105 yang dapat diartikan pendapatan keluarga yang rendah beresiko 2.1 kali untuk terjadi stunting pada anak dan hubungan bermakna terlihat pada jumlah anggota keluarga dengan kejadian stunting pada balita dengan nilai $p=0,024$ dan nilai OR 1.465 yang dapat diartikan anggota keluarga 1.4 kali berpeluang terjadi stunting pada balita. Pada penelitian ini pendapatan keluarga rendah beresiko 2,1 kali terajadi stunting pada balita, hasil ini didukung dengan penelitian yang pernah dilakukan oleh (Haile, 2016) dimana anak-anak dari kelompok kekayaan termiskin memiliki kemungkinan lebih tinggi mengalami stunting pada anak dibandingkan dengan anak dari kelompok terkaya, sehingga pendapatan keluarga menggambarkan tingkat kesejahteraan keluarga. Menurut hasil (Riskesdas, 2013) menyatakan bahwa pendapatan keluarga yang berpenghasilan cukup mampu menurunkan prevalensi stunting.

Keadaan ini tentunya tidak menguntungkan bagi anak-anak dengan jumlah anggota keluarga lebih banyak dan dominan masuk kategori pendapatan keluarga yang rendah, maka anggota keluarga tersebut terutama anak-anak berpeluang untuk tidak mendapat asupan yang lebih baik guna memenuhi kebutuhan tubuhnya.

Hubungan berat badan lahir dengan kejadian stunting didapatkan hubungan yang tidak bermakna, namun dari hasil OR berat badan lahir berpeluang meningkatkan 1.57 kali untuk menyebabkan stunting pada balita. Pada penelitian ini rata-rata mayoritas berat badan lahir normal dari kedua kelompok, yaitu dengan rata-rata berat badan lahir yaitu 2968 gr pada kelompok stunting sedangkan pada kelompok balita normal rata-rata berat badan lahir yaitu $3172 \mathrm{gr}$. 
Hasil analisis didapatkan penyakit infeksi kronis dengan kejadian stunting pada balita tidak memiliki kemaknaan secara statistic dan klinis, namun pernah penyakit infeksi berpeluang 1.37 kali untuk terjadi stunting pada balita. Jumlah penyakit infeksi kronis yaitu sebanyak 54 responden yaitu 31 responden $(3,9 \%)$ pada kelompok stunting dan 23 responden (2,9\%) pada kelompok balita normal, berdasarkan hasil tersebut kasus penyakit infeksi kronis memiliki selisih $1 \%$ antar dua kelompok, dengan perbedaan tersebut belum dapat melihat kasus dominan dari kedua kelompok sehingga tidak dapat mewakili kondisi keterkaitan penyakit infeksi kronis dengan kejadian stunting pada balita di Kabupaten Lombok Timur.

Hasil analisis statistik ASI eksklusif tidak memiliki kemaknaan dengan kejadian stunting pada balita, ini karena proporsi kelompok balita stunting yang tidak memberikan ASI eksklusif lebih banyak $(0,8 \%)$ dibandingkan dengan kelompok balita normal. Pada penelitian ini didapatkan mayoritas balita diberikan ASI eksklusif pada balita yang stunting (91 $\%)$ dibandingkan pada balita stunting $(90,2 \%)$.

Hasil analisis menunjukkan bahwa tidak ada hubungan yang bermakna secara statistik maupun klinis antara panjang badan lahir dengan kejadian stunting pada balita usia 12-59 bulan. Proporsi panjang badan lahir pendek $(<47 \mathrm{~cm})$ lebih banyak ditemukan pada balita tidak stunting. Anak yang lahir dengan panjang badan yang pendek dapat menunjukkan kurangnya asupan gizi ibu selama hamil, sehingga bayi lahir dengan panjang badan lahir rendah karena pertumbuhannya dalam kandungan yang tidak optimal. Selama anak mendapatkan asupan gizi yang memadai dan terjaga kesehatannya, maka kondisi anak yang lahir dengan panjang badan yang pendek dapat dikejar dengan pertumbuhan seiring bertambahnya usia anak .

Jumlah anggota rumah tangga merupakan faktor risiko kejadian stunting, didapatkan lebih dari separuh $(59,4 \%)$ subjek penelitian mempunyai anak $>4$ orang dan hampir $67,6 \%$ sampel masih tinggal bersama dengan anggota keluarga yang lain (kedua orang tua dan saudaran) (Wahdah S, 2012).

Berdasarkan hasil analisis pada tabel 4, model 3 dipilih sebagai model yang baik dalam menjelaskan hubungan hamil usia muda dengan kejadian stunting dengan mengikutsertakan variabel pendidikan, pendapatan keluargadan berat badan lahir karena memiliki nilai $R^{2}$ terbesar dibandingkan model lain yaitu sebesar 0.032 yang dapat disimpulkan bahwa hamil usia muda dengan mengontrol pendapatan keluarga berkontribusi terhadap kejadian stunting sebesar $32 \%$. Pada model ini menunjukkan variabel yang memiliki kemaknaan secara statistik yaitu variabel hamil usia muda dan pendapatan keluarga. Hamil usia muda berpeluang meningkatkan 1.4 kali memiliki balita stunting dengan ( $\mathrm{Cl}$ 95\%:1.020-2.151) dan pendapatan keluarga rendah beresiko 2.1 kali untuk terjadi stunting pada balita dengan ( $\mathrm{Cl} 95 \%$ : 1.352-3.145).

Tabel 4.Analisis multivariate antara variabel bebas, variabel terikat dan variabel luar.

\begin{tabular}{llll}
\hline Variabel & Model 1 & Model 2 & Model 3 \\
\hline Hamil usia muda & & & \\
$-<21$ & 0,039 & 0,043 & 0,017 \\
& 1.481 & 1.474 & 1.59 \\
$-\geq 21$ & $(1.02-2.15)$ & $(1.012-2.147)$ & $(1.086-2.328)$ \\
Pendapatan & & & \\
- Rendah & & 0,000 & 0,000 \\
& & 2.108 & 2.246 \\
- Tinggi & $(1.388-3.194)$ & $(1.472-3.427)$ \\
Jumlah Anggota Keluarga & & & \\
$->4$ & & & 0,004 \\
& & & 1.656 \\
$-\leq 4$ & & & $(1.176-2.331)$ \\
\hline $\mathrm{N}$ & & 798 & 798 \\
$\mathrm{R}^{2}$ & 798 & 0.028 & 0.042 \\
\hline
\end{tabular}




\section{IMPLIKASI KEBIJAKAN}

Strategi penanggulangan stunting dapat dilakukan dengan upaya promotif, prefentif dan kuratif. Berdasarkan temuan penelitian ini dapat diberikan beberapa rekomendasi sebagai berikut :

1. Optimalisasi program kampung KB dalam kegiatan bina keluarga balita fokus pada 1000 HPK yaitu KB, pola asuh dan pemberian ASI.

2. Memaksimalkan kegiatan Bina Keluarga Remaja dan program remaja dengan focus utama penundaan kehamilan pencegahan kejadian kehamilan tidak diinginkan melalui pelaksanaan program Gen-Re dan PIK-R baik formal maupun non formal bekerjasama dengan BKKBN, tokoh agama dan masyarakat.

3. Mengembangkan kreatifitas remaja dalam menangani kerentanan akibat kemiskinan dengan mengoptimalkan program BKKBN dalam meningkatkan ekonomi melalui pelatihan keterampilan berwirausaha, sehingga dapat meningkatkan ekonomi dan nutrisi keluarga.

\section{Daftar Pustaka}

Aryastami NK, 2015. Pertumbuhan usia dini menentukan pertumbuhan usia pra-pubertas (studi longitudinal IFLS 1993-1997-2000) [Longitudinal study, secondary data analisys].

Bhutta, Z. A., Das, J. K., Rizvi, A., Gaffey, M. F., Walker, N., Horton, S., Webb, P., Lartey, A. and Black, R. E., 2013. (2013). Evidence-based interventions for improvement of maternal and child nutrition: what can be done and at what cost? Volume 382(9890), pp. 425-477.

Black RE, Allen,LH., Bhutta, ZA., Caulfield, LE., de Onis, M., Ezzati, M., Mathers, C., Rivera, J., 2008. Maternal and child undernutrition: global and regional exposures and health consequences.. Volume 371, pp. 243-601.

Black, R.E, Victore, C.G, Walker, S.P, et all, 2013. Maternal and child undernutrition and overweight in low-income and middle-income countries.. pp. 427-451.

BPS Provinsi NTB , 2017. Statistik Kesejahteraan Rakyat Provinsi Nusa Tenggara Barat..

BPS, n.d. Situasi Perkawinan Anak di Indonesia Tahun 2017.
Depkes RI, 2009. Profil Kesehatan Indonesia.

Dinkes Provinsi NTB, 2017. Pemantauan Status Gizi Balita Provinsi NTB.

Fall, Caroline H.D, Harspal Singh Sachdev Clive Osmond et all, 2015. Association between Maternal Age at Childbirth and Child and Adult Outcomes in the Offspring: A Prospective Study in Five Low-Income and Middle-Income Countries (COHORTS Collaboration).. Health, Volume 3(7), pp. e366-e377.

Haile, Demewoz, Muluken Azage, Tegegn Mola, and Rochelle Rainey, 2016. Exploring Spatial Variations And Factors Associated With Childhood Stunting In Ethiopia : Spatial And Multilevel Analysis.. BMC Pediatr, Volume 16:19.

Kemenkes RI, 2010. Standar antropometri penilaian status gizi anak. Direktorat bina gizi.

Kemenkes RI, 2016. Situasi Balita Pendek, Info datin pusat data dan informasi kementrian kesehatan RI.

Kementerian Desa, .., 2017. Pembangunan Daerah Tertinggal dan Transmigrasi, Buku Saku Desa dalam Penanganan Stunting.

Osmond C, B. D., 2000. Fetal, Infant, and Childhood Growth Are Predictors of Coronary Heart Disease, Diabetes, and Hypertension in Adult Men and Women.. Environment Health Perspective, Volume 108(Supplement 3), pp. 545-5.

Riskesdas, 2013. Riset Kesehatan Dasar 2013.

SDG, 2017. Profil Singkat Provinsi Nusa Tenggara Barat Tahun 2015.

UNICEF, 2013. Improving Child Nutrition, The Achievable Imperative for Global Progress. United Nations Children's Fund..

Wahdah S, 2012. Faktor Risiko Kejadian Stunting Pada Anak Umur 6-36 Bulan Di Wilayah Pedalaman Kecamatan Silat Hulu Kabupaten 
Kapuas Hulu Provinsi Kalimantan Barat, Kesehatan Masyarakat.

Wahlqvist, M. T. P., 2011. Growth and Ageing, Nutrition and Metabolism Second Edition. Lanham-New, S.A. Macdonald, I.A. \& Roche,
H.M (Ed). Wiley-Blackwell, John Wiley \& Sons Ltd, USA..

Wamani, H., Åstrøm, A.N., Peterson, S., Tumwine, J.K., Tylleskär, T., 2007. Boys Are More Stunted than Girls in Sub-Saharan Africa: A. 